\title{
Efficacy of Teaching Science at Secondary Level through Socio-Scientific Issues-based Argumentation: Study from an Urban Context of Pakistan
}

\author{
Uzma Munir, Sadia Muzaffar Bhutta \\ Aga Khan University, Institute for educational Development
}

\begin{abstract}
Advancement in science and technology calls for enabling students making informed decisions in the context of socio-scientific issues (SSI). This study aimed at exploring the efficacy of teaching science through SSI- based argumentation for improving grade-IX students' argumentation skills with particular focus on the quality and complexity of argumentation. A pre-experiment; pre-post-test design was employed. All of the grade-IX students $(n=44)$ of biology group in an urban public school of Karachi, Pakistan were recruited as a sample. After being taught a unit of eight lessons (45-minutes each) on genetics, students were explicitly engaged in oral and written argumentation for further four sessions (45-minutes each). Data were collected through writing frames before, and after the intervention to gather evidence on progress, students have made in SSI- based argumentation. The data were analysed for complexity and quality of argumentation using the pre-defined analytical frameworks. The findings indicated an overall improvement in complexity of students argumentation with significant difference (Wilcoxon $W=553 ; Z=-4.94 ; p<0.01)$. The magnitude of difference fell in the category of large effect $(r=$ 0.80 ). Similarly, a significant difference (Wilcoxon $W$ $=528 ; Z=-5.00 ; p<0.01)$ was observed in the quality of students' argumentation with a large ( $r=$ 0.832) effect size. Moreover, a model of teaching and learning science through SSI- based argumentation has also been developed.
\end{abstract}

\section{Introduction}

Science and technology have revolutionised the world with its impacts on various aspects of human life. People around the world have appreciated the benefits and advantages offered by the scientific advancements, however, at the same time society has also been confronting with dilemmas such as, socioscientific issues (SSIs) which are appeared due to the expansions in the discussed field. Problems related to science and technology such, as genetic engineering, reproductive technologies, animal testing for medical purpose, gene therapy, genetically modified food, and the dilemmas due to global climate change, energy crisis, managing energy resources and deforestation are examples of some contemporary issues people are confronted with. The discussed situation becomes even more complicated when people receive contradictory information through different sources. People need to evaluate the authenticity of these issues and reliability knowledge claims so that they may make appropriate choices. Decision making is considered critical in the context of SSIs because of the complicated nature of these issues.

The contemporary situation calls for equipping people with skills which help people assess an issue or knowledge claim and enable citizens to make informed decisions about SSIs. It is argued science teaching, and learning can be considered a suitable avenue to inculcate such skills in future adult citizens.

Keeping in view the current demands, Pakistan is among those countries that have been modifying curricula. Recent curricula of basic disciplines of science aim at enabling students to apply science knowledge in order to solve daily life issues. However, with few exceptions, science teaching and learning methods in Pakistan are not according to what curricula are aimed at. Students are passive receivers of knowledge where the teacher is considered authority [10]. The concept of 'respect of teachers' seems to be working with impunity when the students follow 'no argument' rule or even do not talk in the class. In the current situation, students in consider science a boring subject and prefer the subjects other than science in higher grades [5]. It can be argued, the discussed situation of science education in Pakistan calls for developing and testing alternative teaching strategies such as SSI based argumentation in science classrooms for effective implementation of science curricula. The current study aimed to explore the efficacy SSI- based science teaching for improving grade-IX students' argumentation skills focusing on complexity as well as the quality of argumentation. This study can be considered beneficial as it would be an addition to the existing body of knowledge. In addition, it would provide an example of a tried and tested model of SSI-based teaching and learning. Moreover, the study has developed a pattern of intervention for researchers who would like to take the same line of inquiry. 


\section{Research questions}

- Q1. Does the SSI-based teaching contribute towards improving grade IX students' argumentation skills with a particular focus on the complexity of arguments?

- Q2. Does the SSI-based teaching contribute towards improving grade IX students' argumentation skills with a particular focus on the quality of arguments?

\section{Literature review}

Socio-scientific issues (SSIs) have been defined as, open-ended, ill-structured, controversial social matters which have conceptual or procedural background in science and technology, can even have political, social or religious impacts, or may also have multiple solutions [15][20]. People, around the globe, debate over such issues at individual, as well as the societal level. However, as mentioned earlier people also face problems in making decisions regarding SSIs in daily lives [4][7]. School science has been suggested as a suitable avenue to equip students with the skills to deal with SSIs [16][20]. However, SSI-based science teaching demands appropriate teaching strategies that could help students not only learn science concepts but also enable them to generate or evaluate claims with relevant evidence in order to make informed decisions [14] [20]. It is reported when SSI is taught through argumentation it helps students enhance understanding of science content, informal reasoning, argumentation skills, as well as the conceptualisation of nature of science[4][7].

\subsection{Argument and Scientific argumentation}

The word argument has been defined as, assertion or a set of sentences in which a claim is asserted and supported by reasons, evidence or justifications [8]. The term argumentation has been defined as, the process of debate or discussion for creating reasons, evidence, and arguments to validate a claim [20]. It is argued, argumentation can be interpreted in the individual as well as in the social perspective [17][19]. In the context of science education, argumentation refers to the process of making a claim and articulate justifications on the scientific ground for or against any issues like SSIs [20]. It observed when SSI is taught through argumentation; students are actively engaged in the relevant realworld topic where based on science knowledge they analyse, interpret, evaluate, may refute, make inferences, and give explanations and arguments over SSI-based scenarios [13]. This means SSIbased argumentation enables students to apply science learning to real-life situations and make informed decisions. Hence, the discussed strategy helps students to understand how science is related to daily life, personal problems and social issues or global concerns [14].

SSI- based teaching has been explored in a number of contexts. However, the discussed area has hardly been investigated in the context of Pakistan, and only one unpublished master's thesis [1] has been identified. Hence, there is a need for studies focusing on SSI-based teaching in the context of Pakistan.

\subsection{SSI-based Argumentation: Philosophical View}

Various theoretical perspectives have been employed to explain SSI-based argumentation as a teaching strategy. However, a common consensus is found for the premise that SSI-based argumentation is rooted in Vygotsky's theory of socialconstructivism [3] [4] [7] [11]. Social constructivism is founded on the premise; knowledge is constructed as a result of the interaction between individual and environment [2]. The environment may constitute a classroom, teacher, student, resource, context, language, and culture [3]. In an argumentation classroom, students can actively participate, interact, negotiate and collaborate with peers and the teacher. Learners get an opportunity to share, accept or refute their existing understanding, new ideas, contextual and cultural beliefs, and learn new concepts. Hence, students actively participate in the social construction and reconstruction of knowledge in the form of scientific explanations [11].

\subsection{Informal Reasoning}

Argumentation about SSI comprises informal reasoning [19]. The type of reasoning and thinking involved while discussing ill-structured open-ended issues that may have multiple solutions, e.g. SSIs has been termed as informal reasoning [8]. The informal reasoning demands an ability to pose a question, reason out, weigh up risk or benefits, and evaluate the information from all possible angles to make an informed decision [9]. Informal reasoning has been considered a fundamental element of SSI- based argumentation. It has also been considered as an indicator of the quality of arguments in the context of SSI-based argumentation.

There have been defined three categories of IR [15]. The categories are as follows; rationalistic which is cognitive, reasoning using scientific facts and knowledge, emotive-reasoning representing care and empathy, or intuitive-reasoning based on immediate gut responses. Rational reasoning has been considered better over emotive and intuitive informal reasoning. Likewise, emotive reasoning has 
been considered better over intuitive, informal reasoning.

\subsection{Toulmin model of argumentation}

To understand the structure or complexity of daily life arguments in different situations, a British philosopher Stephen Toulmin developed an argumentation scheme in 1958 - Toulmin's Model of Argumentation (TMA) [18]. The Figure 1 presents the model briefly.

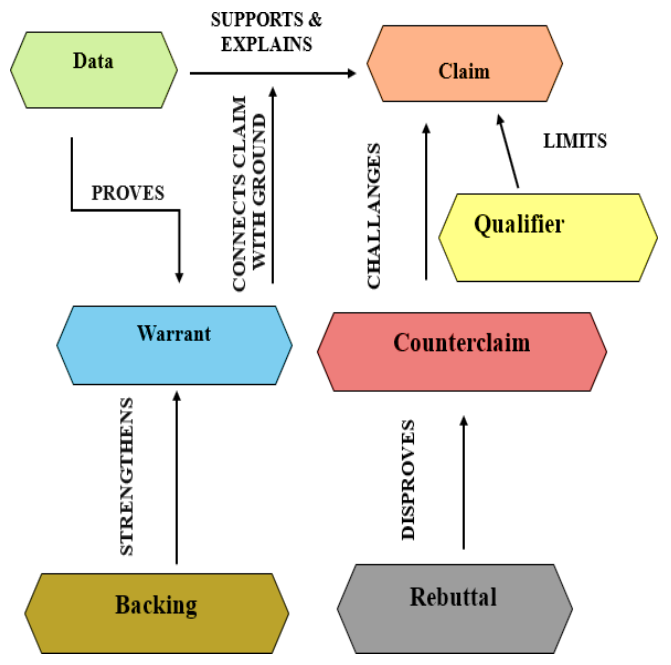

Figure 1. Toulmin's model [18]

As demonstrated in figure 1, the TMA structures an argumentation into six components; claim, data, warrant, backing, qualifier, counterclaim, and, rebuttal. All elements of the Toulmin's model interact and depend on each other to form a complete argument. The use of the Toulmin's model has been advocated in order to foster learners' argumentation skills [7].

\section{Method}

The current study was conducted under the quantitative research paradigm. The pre-experiment, one group pre-test-post-test design was employed to determine improvement in complexity and quality of grade-IX students' argumentation.

\subsection{Sample and sampling}

All of the Grade-IX students $(n=44)$ in an urban public secondary school of Karachi, Pakistan, were recruited as a sample through convenience sampling. However, 38 students responded to the pre-and posttest. The age of the students ranges from 13 to 17 years $(\mathrm{M}=14.4 ; \mathrm{SD}=0.95)$. It was single-sex school specified for girls only.

\subsection{Pre-Intervention phase}

The current intervention passed through stages of detailed planning before execution. Since, the researcher was supposed to teach the intervention class therefore, the process began with preintervention classroom observations made by the researcher. The sample class (grade-IX) taught by the biology teacher was observed twice with a gap of four days to tweak intervention accordingly. The Figure 2 presents vignette developed to demonstrate the pre-intervention classroom observation

As the researcher set in the class, it was noticed the students were chirping like birds but, it remained only until the biology subject teacher entered the classroom. With the teacher's presence, everyone got into silence, the room quietens. The teacher requested for books on every table, and within moments the books were pulled out of the bags. The teacher instructed the students to turn to page.... And there, she started. She read out the whole topic from the textbook with just a few pauses where she translated and explain briefly the meaning of the terms; 'digestion' pseudopodia', and 'intracellular' in the Urdu language as the topic was 'the digestive system of Amoeba'. The teacher continued to read aloud from the textbook. The students found looking at the book during the whole session as they were trying to follow what the teacher was going through. Any discussion, discourse, debate or argumentation was not observed. And this is exactly what observed in the second classroom observation. However, this time the topic was 'digestion in human beings'.

Figure 2. Vignette: Pre-intervention Classroom Observation

The observations were made to get a sense of current practices whether SSI-based science teaching had already been implemented or not (i.e. to inform the intervention and not to evaluate the teacher). Therefore, no formal observation tool was employed. It was revealed there was hardly any, interaction like discussion, debate or argumentation in the classroom which laid a foundation to implement strategy of argumentation. Besides, it was also observed that the biology teacher relied only on delivering content from a biology textbook published by the local textbook board. The respective board publishes textbooks according to the national curriculum of biology. However, the mentioned textbook contains knowledge and information to a certain limit as per curriculum instruction. Whereas, studies in the field of SSI- based argumentation suggest the provision of in- depth knowledge of a concept and related issues in order to enable students generate better 
argumentation [12] and [20]. Moreover, researchers and educationists, also support the use of books, newspapers, magazines, and the internet resources to help students gain strong content knowledge and information about related SSIs [4], [20]. Similarly, students' involvement in classroom activities, peer interaction, and teacher-student communication are also considered fundamentally important components of SSI-based argumentation [12].

Together, the classroom observations and literature review guided the development of an instructional manual; an Argumentation-Based Science Teaching Support (ABSTS) Manual consisted of two core sections. The first part was based on 12 day-to-day lesson plans and resources. The plans and resources helped researcher to teach selected concepts of genetics (including, DNA structure, replication and transcription of DNA, Inheritance, mutations, genetic diseases and genetic engineering) and SSI-based, argumentation with the help of SSI-based scenarios [4][19][20]. All lessons plans included teaching strategies based on social constructivism which provided students and teacher opportunities for interaction (e.g. student-student, student-teacher). The Table 1 demonstrates some of the strategies included in ABSTS-manual that provided students opportunities for social interaction. The second part of the ABSTS manual mentioned teacher's role for better delivery of content and implementation of argumentation. While focusing on the theory of constructivism strategies for modelling, coaching, scaffolding, reflection, and probing were mentioned for teachers in the second part of the manual. In addition, instructions about the use of specific kind of argumentative talk were also given.

Table 1. Teaching Activities Based on Social Constructivism

\begin{tabular}{|c|c|c|c|}
\hline & Activities & $\begin{array}{l}\text { Genetics } \\
\text { Concepts }\end{array}$ & Time \\
\hline 1 & Group discussion & $\begin{array}{l}\text { Picture analysis } \\
\text { "From DNA } \\
\text { to the chromosome.' }\end{array}$ & $\begin{array}{c}10 \\
\text { minutes }\end{array}$ \\
\hline 2 & Group work & $\begin{array}{l}\text { Let's build } \\
\text { our DNA.", }\end{array}$ & $\begin{array}{c}15 \\
\text { minutes }\end{array}$ \\
\hline 3 & $\begin{array}{l}\text { Gallery walk to } \\
\text { view survey } \\
\text { findings }\end{array}$ & $\begin{array}{l}\text { Symptoms, } \\
\text { causes and cure } \\
\text { for diabetes }\end{array}$ & $\begin{array}{l}15 \\
\text { minutes }\end{array}$ \\
\hline 4 & Simulation & DNA transcription & $\begin{array}{c}15 \\
\text { minutes }\end{array}$ \\
\hline 5 & $\begin{array}{l}\text { Whole class } \\
\text { argumentation }\end{array}$ & $\begin{array}{l}\text { Genetically } \\
\text { Modified Food }\end{array}$ & $\begin{array}{c}20 \\
\text { minutes }\end{array}$ \\
\hline
\end{tabular}

More elaborately, in the year 2006 Simon, Erduran, and Osborne reported high school students of such classes provided better argumentation where teachers used specific kind of argumentative talk. Based on these findings, Simon and co-researchers provided a framework of argumentative talk for teachers that may enable students to generate better argumentation. The mentioned framework was adapted and included in the ABSTS manual.

The researcher used the specific argumentative talk while teaching argumentation to the intervention class in order to achieve teaching and learning goals set for students. Table 2 demonstrates examples of specific talk and relevant classroom utterance. It is worthwhile to mention that the development of the ABSTS-manual was an iterative process of revising and refining the document. The drafts of the manual were shared at different stages with practitioners and researchers (teachers, subject coordinator and teacher educators) to get feedback for further improvement before the intervention was launched.

Table 2. Classroom Examples of the Teacher's Argumentative Talk

\begin{tabular}{ll}
\hline $\begin{array}{l}\text { Types of specific } \\
\text { teachers' talk }\end{array}$ & $\begin{array}{l}\text { Teacher's talk: Examples } \\
\text { room the classroom }\end{array}$ \\
\hline $\begin{array}{l}\text { Helping to take a } \\
\text { position }\end{array}$ & $\begin{array}{l}\text { What is your stance, what do } \\
\text { you think, should people } \\
\text { opt for GMF or not? }\end{array}$ \\
$\begin{array}{l}\text { Explaining with } \\
\text { examples the } \\
\text { components of } \\
\text { Toulmin's model }\end{array}$ & $\begin{array}{l}\text { Look! What student -12 } \\
\text { (pseudonym) has just said: } \\
\text { "Maryam should not marry } \\
\text { unless she gets herself tested } \\
\text { for the Huntington disease." } \\
\text { This is limitations of her } \\
\text { decision, and it is called } \\
\text { qualifier. } \\
\text { learn valuing }\end{array}$ \\
\hline $\begin{array}{l}\text { Playing devil's advocate } \\
\text { argumentation }\end{array}$ & $\begin{array}{l}\text { Wouldn't it be disappointing } \\
\text { for her if she gets Huntington } \\
\text { disease test positive? }\end{array}$ \\
\hline
\end{tabular}


All the practitioners and researchers had a background in teaching science in general and more specifically in SSI-based argumentation (see Table 2). The feedback guided the researcher for what, when and how content and argumentation skills should be taught and how to maximise available time

\subsection{Intervention}

The intervention period spanned over three weeks during which four lessons (45 minutes each) per week were delivered. The researcher who has a background in genetics and has training and experience in teaching biology and SSI-based argumentation taught the intervention class. The content related to genetics was taught during the first eight lessons, whereas, rest of the four sessions were consumed in teaching, learning, and practising SSIbased argumentation.

\subsection{Data collection tool}

To measure participants' written argumentation skills, a writing frame was developed consisted of an SSI-based scenario and six open-ended guiding questions (Appendix A). The mentioned writing frame was employed as a data collection tool. The particular fictitious gene therapy scenario was previously used by Kolarova, Hadjiali, and Denev in their study [6]. It was used in the current study with prior permission from the authors The scenario presented a hypothetical situation related to a socioscientific issue. After reading the scenario, students were supposed to decide whether the couple should accept the offer of gene therapy? Once, taken the stance, students were supposed to generate argumentation in favour of their decision with the help of guiding questions. Each of the guiding questions represented one component of Toulmin's model. The writing frame was also translated in Urdu for the students who would like to respond in the native language.

\subsection{Data collection}

The pre-test was conducted a day before intervention whereas the post-test was taken the next day to the last lesson. The data were collected in an examination set up in order to avoid peer-peer or peer-teacher influence. The same tool (writing frame) was used for pre and post-test data collection.

\subsection{Data Analysis}

To make sense of the data, the qualitative data (students' argumentation on writing frames) were quantified using two separate analytical schemes for complexity and quality of students' argumentation. The quantification provided a context for the categorisation of students' responses into levels of complexity and quality of argumentation.

\subsubsection{Analytical schemes: Complexity of Argumentation}

To analyse and assign a level of complexity to each student's argumentation, an analytical scheme based on the Toulmin's model was adapted which had previously been used by Venville and Dawson [19]. This analytical framework was modified because the original framework did not include 'rebuttal'. Since 'rebuttal' is considered an integral part of the Toulmin's model [18]. Therefore, the mentioned analytical framework was adapted to add a component of rebuttal. The Table 3 demonstrates the adapted version of the analytical scheme representing levels and descriptions of levels for the complexity of an argumentation.

Table 3. Framework for the Analysis of the Complexity of Argumentation

\begin{tabular}{ll}
\hline Levels & Description \\
\hline Level-1 & $\begin{array}{l}\text { Claim } \\
\text { decision only) }\end{array}$ \\
Level-2 & $\begin{array}{l}\text { Claim and data (evidence supporting the } \\
\text { claim)/ warrant (the relationship } \\
\text { between claim and data) }\end{array}$ \\
Level-3 & $\begin{array}{l}\text { Claim, data/warrant and backing } \\
\text { (assumptions to support warrant) }\end{array}$ \\
Level-4 & $\begin{array}{l}\text { Claim, data/warrant, backing, and } \\
\text { counterclaim (claim against the first } \\
\text { claim) }\end{array}$ \\
Level-5 & $\begin{array}{l}\text { Claim, data/warrant, backing, and } \\
\text { qualifier (limitations of one's claim) }\end{array}$ \\
\hline Level-6 & $\begin{array}{l}\text { Claim, data/warrant, backing, } \\
\text { counterclaim , qualifier and rebuttal } \\
\text { (counter-argument to acounterclaim) }\end{array}$ \\
\hline
\end{tabular}

According to this analytical framework, claim, data, warrant, backing, counterclaim, qualifier, and rebuttal are the structural components of an argumentation. The framework consisted of six argumentation levels based on to what extent students have used component of the Toulmin;s model in their arguments. Those students were ranked level-1 who only made a claim. If an argumentation consisted of a claim with evidence and/or warrant to support the claim, the 
argumentation was assigned level-2. On providing claim, data/warrant, backing the argumentation got the level-3 position. Level-4 was assigned to the argumentation, which included the claim, data/warrant, backing and counterclaim. Students' responses with the claim, data/warrant, backing, counterclaim, and qualifier were given level-5 whereas, argumentation that contain all six components of the Toulmin's model, including rebuttal, were categorised as the level-6 argumentation. All pre- and post-tests responses were analysed through this scheme and levels of complexity were assigned accordingly

4.6.2. Analytical schemes. Complexity of Argument -ation, Toulmin;s model of Argumentation does not enable researchers to explore the quality of argumentations, i.e. understanding of underlying science concept, therefore, for the current study, an analytical framework was adopted which was develop by Venville and Dawson [19] based on informal reasoning to evaluate the quality of argumentation. This scheme analyses the quality of argumentation with the help of a type of informal reasoning in any argumentation. The Table 4 represents a framework with categories of the informal reasoning that determine the quality of argumentations.

Table 4. Framework for the Analysis of Quality of Argumentation

\begin{tabular}{ll}
\hline Category & Description \\
\hline $\begin{array}{l}\text { Rationalistic } \\
\text { (category } \\
\text { three) }\end{array}$ & $\begin{array}{l}\text { Logical, use scientific } \\
\text { understanding and language, } \\
\text { weighs up risks and benefits, } \\
\text { advantages and disadvantages }\end{array}$ \\
$\begin{array}{l}\text { Emotive } \\
\text { (category } \\
\text { two) }\end{array}$ & $\begin{array}{l}\text { Emotional response, care, } \\
\text { empathy, or sympathy } \\
\text { towards stakeholders. }\end{array}$ \\
$\begin{array}{l}\text { Intuitive } \\
\text { (category } \\
\text { one) }\end{array}$ & $\begin{array}{l}\text { Gut feeling, immediate } \\
\text { response, strongly held belief, } \\
\text { often a negative response, } \\
\text { personal }\end{array}$ \\
$\begin{array}{l}\text { Not } \\
\text { Applicable } \\
\text { (category } \\
\text { zero) }\end{array}$ & Not able to be classified \\
\hline
\end{tabular}

The presented scheme analyses the quality of informal reasoning through the presence of correct and relevant science concept in an argumentation. Each statement in any, student's response was categorised as rationalistic, emotive, and intuitive or not applicable by the pattern of informal reasoning it presents.

Students' responses were analysed according to the mentioned framework. Categories (i.e. zero, one, two or three) were assigned to each response on the basis of the presence of more intuitive, emotive or rationalistic informal reasoning respectively. For example, if an argumentation has more rationalistic statements than emotive and intuitive, the response was assigned level-1. Similarly, an argumentation was assigned level two if it had more emotive statements. Likewise, level-3 was assigned to an argumentation which had more intuitive statements. Moreover, those responses that were without any written statements or with more statements that were understandable were considered 'not applicable' and were assigned category zero. Furthermore, if students presented an equal number of emotive and intuitive statements, such responses were assigned category two, and if students presented an equal number of rational reasoning and intuitive or rationalistic and emotive, they were placed in category three.

\subsection{Inter-rater reliability}

In order to establish the reliability of the two analytical schemes, 12 responses of participant students (six from the pre-test and six from posttest) [15.78\%] were rated blind and independently by two raters. Both raters had experience of this kind of rating. The degree of agreement between two raters was measured through weighted Kappa. The kappa value for the complexity and quality of argumentation were calculated as 0.85 , and 0.85 respectively indicating strong agreement between raters. Getting the same kappa values for both of the constructs was only a coincidence.

\section{Results}

To answer the two research questions, the data were analyzed twice by employing two separate analytical schemes for assessing complexity as well as the quality of students' argumentations Each statement in a student's responses on the writing frame was the unit of analysis. Results of analysis are presented as follows.

\subsection{Complexity of argumentation}

To gauge the difference in pre-and post-test complexity of students; argumentation the pre- and post-tests responses were compared, and differences were sought. Findings revealed students generally, produced arguments with better complexity during post-test as compared to pre-test. Figure 3 illustrates a graphical representation of pre-and post-test 
differences in the complexity of grade-IX students' argumentation.

The graph demonstrates a clear shift towards more complex argumentation after the intervention. In other words, more of the post-test responses in general were found better in complexity as compared to pre-test. Most importantly, a noticeable decrease has been found in level-2 of complexity after intervention as compared to pre-test. The decline in level-2 indicates that students $(\mathrm{n}=5 ; 13 \%)$ who were able to produce claim with at least one evidence were able to construct more complex argumentations after the intervention. Evidently,

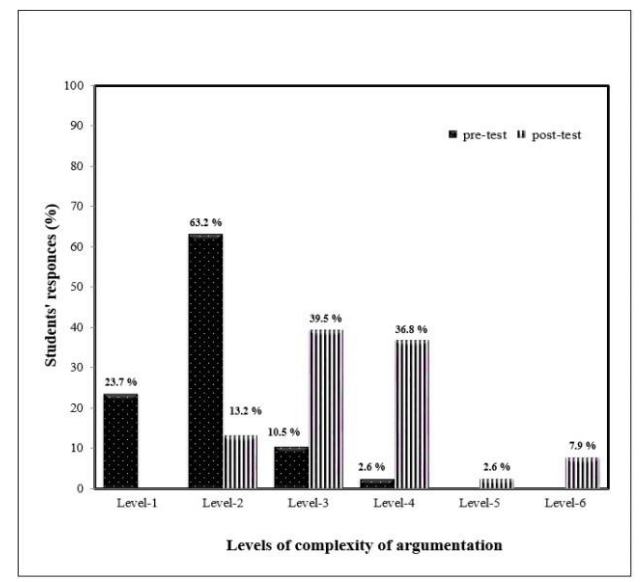

Figure 3. The Pre-and Post-Test complexity of Argumentation

The pre-and post-test complexity of argumentation before the intervention, almost twothirds of students $(n=24 ; 63.2 \%)$ found at level-2 which means a majority of students provided only claim with at least one evidence. Approximately, a quarter of the sample $(n=9 ; 23.7 \%)$ fell in level-1, they just made a claim for or against the given dilemma. There was only a minority $(n=4 ; 10.5 \%)$ which qualified for level-3, as their argumentation consisted of claim, data/warrant, and backing. Interestingly, only one student $(2.6 \%)$ managed to built a relatively 'complex' argumentation with the claim, data/warrant, backing, and counterclaim and was, assigned level-4. None of the students qualified for the highest levels of complexity (levels-5 and 6) before the intervention.

The graph further mentions a majority of posttest responses fell either in the category of level-3 $(n=15 ; 39 \%)$ or level-4 $(n=14 ; 37 \%)$. This means a little more than one-third of the students were able to construct argumentation with the claim, data/warrant, and backing (level-3) or built argumentation with the claim, data/warrants, backing, and counterclaim (level-4) after the intervention. None of the respondents found at level- In other words, after the intervention. all of the students were placed at a higher level than level-1. However, only one student, $(\mathrm{n}=1 ; 3 \%)$ assigned level-5 who provided claim, data, warrant, backing, counterclaim. and qualifier Furthermore, only a few students, $(n=3 ; 8 \%)$ could reach the highest level of complexity (i.e. level-6).

Table 5. Improvement in Complexity: Example from Student's Argumentations

\begin{tabular}{ll}
\hline $\begin{array}{l}\text { Levels of } \\
\text { complexity }\end{array}$ & $\begin{array}{l}\text { Argumentation by student } 1 \\
\text { (Pseudonym) }\end{array}$ \\
\hline $\begin{array}{l}\text { Pre-test } \\
\text { (level-2) }\end{array}$ & $\begin{array}{l}\text { Yes, it is beneficial to accept the } \\
\text { offer (claim) because the couple } \\
\text { will not have to raise an unhealthy } \\
\text { child (data). The family can save } \\
\text { the money (warrant) that otherwise } \\
\text { they would have to spend on the } \\
\text { medication of a child with the cystic } \\
\text { fibrosis disease }\end{array}$ \\
Post-test \\
(Level- 6)
\end{tabular}

Moreover, the difference in pre- and post-test complexity of students' argumentations were found to be statistically significant [Wilcoxon $\mathrm{W}=553 ; \mathrm{Z}=$ $-4.940 ; p<0.01]$. The magnitude of difference was found substantial $(\mathrm{r}=0.80 ; \mathrm{r} 2=0.64)$ which may conclude that teaching science through argumentation about socio-scientific issues accounted for $64 \%$ variation in the complexity of students' argumentations. Table 5 presents example of a student's pre- and post-tests responses who 
improved from the level 2 to the level 6 after instructions.

\section{Pre-test (level-2)}

Yes, it is beneficial to accept the offer (claim) because the couple will not have to raise an unhealthy child (data). The family can save the money (warrant) that otherwise they would have to spend on the medication of a child with the cystic fibrosis disease.

The Post-test (Level- 6) Yes! The couple should accept the offer of GLGT (Claim) because through this therapy defected CFTR gene will be replaced with the healthy gene in the cells of the embryo (data), which will lead to the birth of a healthy child (warrant).The child will neither have to take a significant dosage of medicines nor would the child have to use breathing aid machines (backing). If someone disagrees, he might claim that the couple should not opt for GLGT because if retrovirus inserts in any other place instead of the target location, this may cause mutation in other genes (counterclaim). I think using the virus as a vector to carry the gene to the target location is not advisable. Scientists should think and try out some other vectors (qualifier). Moreover, keeping the viral vector very peculiar to the target can lead to the successful gene therapy (rebuttal).

\subsection{Quality of argumentation}

To figure out differences in pre-and post-test quality of argumentation, students' responses were categorised into types of informal reasoning. The pre- and post-tests responses were compared, and the differences were sought. The findings revealed an overall improvement in the quality of students' argumentation from pre-to post-tests. The comparison is represented graphically in Figure 4 below.

The Figure 4 illustrates, on the whole, a noticeable improvement in the quality of students' argumentations from pre- to post-test. It determines that prior to intervention students demonstrated, notapplicable $(n=14 ; 36.8 \%)$, emotive $(n=14 ; 36.8 \%)$ or intuitive $(n=10 ; 26.3 \%)$ types of informal reasoning. More importantly, none of the students could generate a rationalistic response before the intervention. Whereas, post-test findings reveal a greater increase in the level of quality of students' argumentations. Most of the students' responses $(\mathrm{n}=28 ; 73.7 \%)$ were found rationalistic, while the rest of responses were categorised as emotive. Interestingly, none of the respondents produced intuitive or not applicable argumentations in the post-test. Results indicated after the intervention students were able to build better quality argumentation with either more emotive or more rationalistic statements.

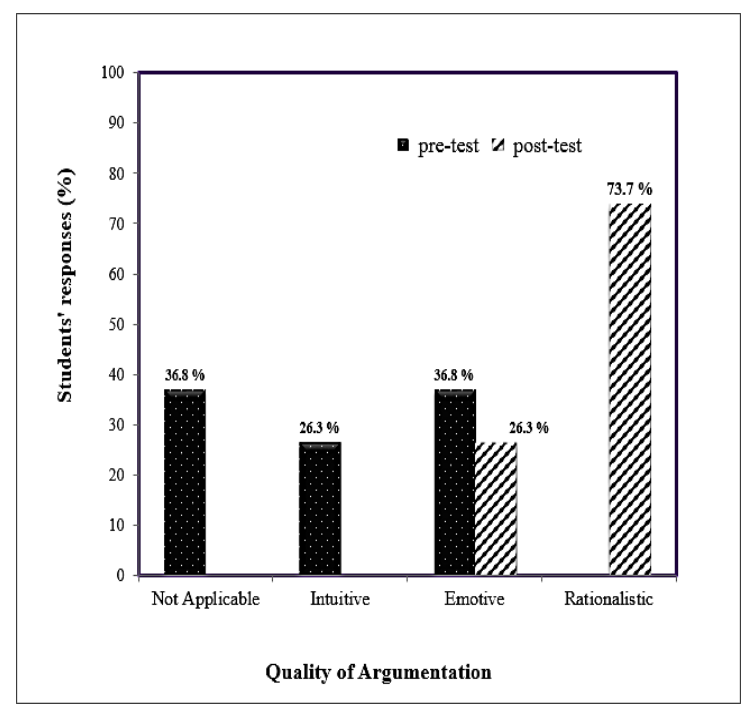

Figure 4. The Pre-and Post-test Quality of Argumentation

The difference in pre- and post-tests' quality of students' argumentation was also found to be statistically significant (Wilcoxon $\mathrm{W}=528 ; \mathrm{Z}=$ 5.005; $\mathrm{p}<0.01$ ). In addition, on the basis of the magnitude of the difference $(r=0.83 ; \mathrm{r} 2=0.68)$, it can be concluded, teaching science through argumentation about socio-scientific issues accounted for $68 \%$ variation in the quality of students' argumentations.

To represent an improvement in the quality of students' argumentations (a type of informal reasoning) from pre- to post-test, the response of students has been presented an example in Table 6 . Indicators of the type of informal reasoning (intuitive, emotive, rationalistic or not applicable) have been added in parentheses.

Yes, the couple should accept scientists' offer. I have taken this decision because I feel that that couple has no other choice (not applicable). The family will otherwise not remain healthy (Not applicable). However, I will change my decision if the child will not survive (not applicable).

Post-test (Rationalistic) Yes, the couple should accept scientists' offer because, through germline gene therapy, child's malfunctioning gene will be replaced by healthy gene and hence a normal child will be born (rationalistic). Also, the disease will not transfer to the next generation (rationalistic). However, there can be some disadvantages of my decision like a retrovirus can cause mutations if DNA carried by vector does not inserted in specific target location (rationalistic). The example shows before the intervention student-3 produced the response that falls under the category of notapplicable. 
Table 6. Improvement in Quality: Example from Students' Argumentation

\begin{tabular}{ll}
\hline $\begin{array}{l}\text { Levels of } \\
\text { quality }\end{array}$ & $\begin{array}{l}\text { Argumentations of student 3 } \\
\text { (pseudonym) }\end{array}$ \\
\hline Pre-test & $\begin{array}{l}\text { Yes, the couple should accept } \\
\text { scientists' offer. I have taken this } \\
\text { decision because I feel that that } \\
\text { applicable) } \\
\text { couple has no other choice (not } \\
\text { applicable) The family will } \\
\text { otherwise not remain healthy (Not } \\
\text { applicable) However, I will } \\
\text { change my decision if the child } \\
\text { will not survive (not applicable) }\end{array}$ \\
Post-test \\
(Rationalistic)
\end{tabular}

Contrastingly, after the intervention, student-3 produced a rationalistic argumentation that was mainly based on logical statements showing scientific understanding. The discussed student first claimed that 'the couple should opt for the offer the GLGT in the post-test and then justified it by telling that scientists will insert a healthy version of the defected gene through the GLGT. The claim was further strengthened by pointing out some possible scientific disadvantages of the decision (counterclaim) that there are, however, chances of mutation/s in case of insertion of a healthy gene to a wrong location.

\subsection{A model of Teaching and learning SSI- based Argumentation}

The focus of the current study was not to generalize the findings rather explore whether students in Pakistani context can be engaged in argumentation in the context of Pakistan where a dearth of research has been observed. However, through this intervention, a model is evolved for teaching science through SSI-based argumentation. The Figure 5 demonstrates the model in detail.
As evident, the model presents factors that can be considered a prerequisite for the implementation of SSI-based science teaching. For example, planning lessons with enriched content, selection of relevant contemporary SSI as well as research-based teaching activities grounded in the theory of social constructivism that could promote students' argumentation skills, e.g. discussions, debates, roleplays, simulations and group work, use of the Toulmin's model, and employing writing frames. The model would help teachers to take SSI-based science teaching to the classroom. The model also indicates need to enrich the curriculum for teacher education by including the element of 'Teaching of Contemporary Issues in Science'. It would also help researchers who would like to take the same line of inquiry. The model would serve as a reference for textbook writers to update school science textbook by adding contemporary socio-scientific issues related to various science topics.

\section{Discussion and Conclusion}

The current study investigated the efficacy of SSI- based argumentation for improving argumentation skills of grade-IX students in a public school in an urban context of Pakistan. The findings showed significant improvement in the quality and complexity of students' argumentation skills. This may imply SSI-based argumentation has the potential to enhance students' argumentation skills in the mentioned context. The results point to an overall improvement in argumentation skills of grade-IX biology students. The pre-test results reveal students tendency to generate less complex argumentation with lower quality whereas, the post- test findings showed a reversed pattern. The findings also strengthen Kuhn's notion [8] that argumentation skill exists in students but these skills are in the dormant stage, and if provided with opportunities to proceed, students may show development in discussed skills. There could be various contributing factors for an overall improvement. Such as, exposure to SSIbased argumentation that provides students with an opportunity to involve in learning and applying content knowledge according to the Toulmin's model. Perhaps, the use of Toulmin's model did not only help students to learn the structure of argumentation but also enhanced content knowledge when students utilised science information to formulate argumentation. Furthermore, the guiding questions in writing frames probably made it easier for students to make structured argumentations. It can also be assumed that the use of scientific knowledge to generate different components of an argumentation might have enhanced students' knowledge of genetics. 


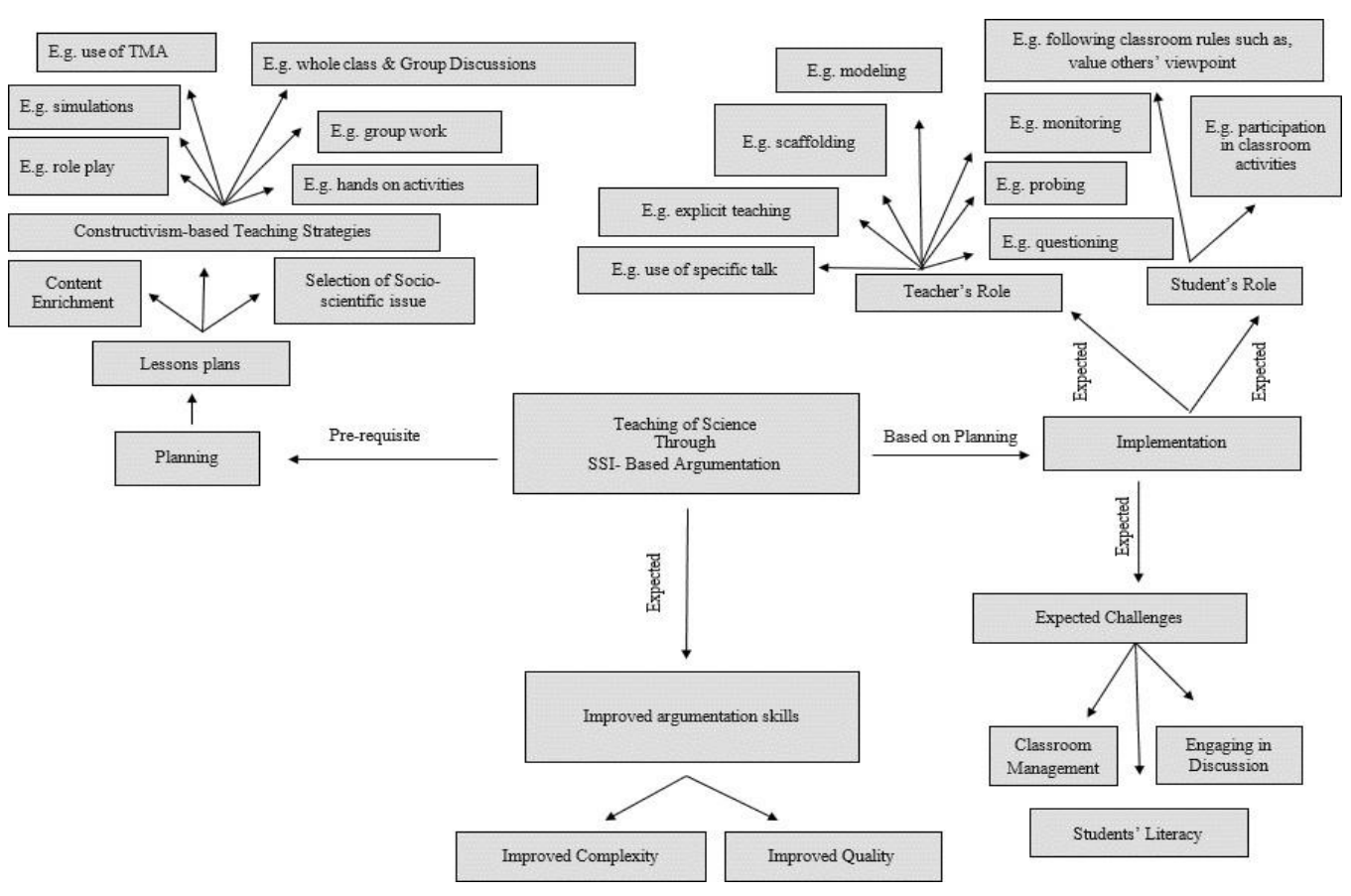

Figure 5. A Model of Teaching and Learning Argumentation

The findings of the current study show that after the 3-week intervention (limited experience with SSI) students provided argumentation with better science knowledge which implies that students can learn science content related to genetics through SSIbased instructions. These findings also support the argument that SSI-based instructions have the potential to help students learn science content. However, it does not imply that all students show similar improvements in content knowledge in the context of genetics in response to SSI-based instruction as not all students get similar gains.

Another implication of the findings would be that students can improve their written argumentations with the help of writing frames which are based on Toulmin's model of argumentation. However, the extent of possible improvement is an area that needs further exploration.

The encouraging findings of the current study regarding students gain in content knowledge as well as argumentation skills implicates that the model developed for SSI-based teaching in the context of SSI can serve as a contextualised model of SSIbased science teaching. However, further exploration with bigger and more varied sample is needed to achieve more generalisability.

During the discussed study, students experienced pedagogies that are different from traditional methods which might help students learn better and show better performance in post-test. It is assumed that the pedagogical approaches were more engaging as compared to standard practice. This implicates that constructivist teaching strategies can help students to get motivated, engaged, participate and learn the concepts better. The findings also suggest that the use of specific kind of teacher's talk which was based on argumentative language might have also helped teachers to implement SSI-based teaching and learning. This implicates that teachers and researchers need to focus on specific kind of talk while planning and implementing SSI-based teaching. Besides, though students have generated better argumentation after the intervention, however, based on current findings, it cannot be assumed that students would be able to transfer the acquired skills from the context of genetics to another context of biology which was not taught. Exploring the transfer of argumentation skills was beyond the scope of this study. Nonetheless, it is argued that the ability to argue over SSIs from different context need to be considered crucial in order to make informed decisions The model of teaching and learning science through SSI- based argumentation indicates a simple input-out model would not work for enhancing students' argumentation skills. Writing frame and the triggers/case studies/scenarios may have worked as an anchoring point for students' to shape and voice their thinking; however, there were many other factors at various levels which have contributed. Therefore, it is argued, SSI-based argumentation should not be considered as a panacea or silver bullet to enhance students' argumentation skills rather there are so many mediating factors (teachers' role, students' role, classroom dynamic, specific teaching 
material which play an essential role in this equation. However, keeping the benefits of the strategy, e.g. helping students to become informed, critical and scientifically literate citizen, and efforts can be made to implement it.

\section{References}

[1] Chang, A., (2007). Innovative strategies to promote students' argumentation in science (Unpu blished master's dissertation) Aga Khan University, Karachi, Pakistan.

[2] Driver, R., Asoko, H., Leach, J., Mortimer, E., and Scott, P., (1994). Constructing Scientific Knowledge in the Classroom. Educational Researcher. DOI:10.2307/1176933.

[3] Driver, R., Newton, P., and Osborne, J., (2000). Establishing the norms of scientific argumentation in classrooms. Science Education, 84(3), 287. DOI:10.1002/(sici)1098-237x(200005)84:3<287::ai d-sce1>3.3.co;2-1.

[4] Foong, C., and Daniel, E. G., (2012). Students' argumentation skills across two socio-scientific issues in a Confucian classroom: Is transfer possible? International Journal of Science Education, 35(14), DOI:1080/09500693.2012.697209.

[5] Jessani, S. I., (2015). Science Education: Issues approaches and challenges. Journal of Education and Educational development, 2 (1), 79-87.

[6] Kolarova, T., Hadjiali, I., and Denev, I., (2014). High school students' reasoning in making decisions about socio-ethical issues of genetic engineering: Case of gene therapy. Biotechnology and Biotechnological Equipment, 27(2),3737- 3747. DOI: 10.5504/BBEQ.2012.0133.

[7] Klosterman, M. L., and Sadler, T. D., (2010). Multilevel Assessment of Scientific Content Knowledge Gains Associated with Socioscientific Issues-based Instruction. International Journal of Science Education, 32(8), DOI:10.1080/0950069090 2894512.

[8] Kuhn, D., (1991). Conclusion. In The skills of argument. Cambridge: Cambridge University Press.

[9] Means, M. L., and Voss, J. F., (1996). Who Reasons Well? Two Studies of Informal Reasoning Among Children of Different Grade, Ability, and Knowledge Levels. Cognition and Instruction, 14(2), DOI: $10.1207 / \mathrm{s} 1532690 x$ ci1402_1.

[10] Nayyar, A. H. (2016). March 4). Science education in Schools. The Dawn [Karachi].
[11] Newton, P., Driver, R., and Osborne, J., (1999). The place of argumentation in the pedagogy of school science. International Journal of Science Education, 21(5), DOI: 10.1080/095006999290570.

[12] Osborne, J., Erduran, S., and Simon, S., (2004). Enhancing the quality of argumentation in school science. Journal of Research, in Science and Technology, 41(10), DOI: 10.1002/tea.20035.

[13] Sadler, T. D., (2003). Informal reasoning regarding socio-scientific Issues: A critical review of research. Journal of Research in Science Teaching, 41(5), DOI: 10.1002/tea.20009.

[14] Sadler, T. D., Klosterman, M. L., and Topcu, M. S., (2011). Learning science content and socioscientific reasoning through classroom explorations of global climate change. In T. D. Sadler (Ed.), Socio-scientific issues in the classroom Teaching, learning and research. Dordrecht: Springer.

[15] Sadler, T. D., and Zeidler, D. L., (2004a). Patterns of informal reasoning in the context of socio- scientific decision making. J. Res. Sci. Teach, 42 (1), DOI:10.1002/tea.20042.

[16] Sadler, T. D., and Zeidler, D. L., (2004b). The significance of content knowledge for informal reasoning regarding socio-scientific issues: Applying genetics knowledge to genetic engineering issues. Science Education. DOI:10.1002/sce.20023.

[17] Simon, S., Erduran, S., and Osborne, J., (2006). Learning to Teach Argumentation: Research and development in the science classroom. International Journal of Science Education, 28(2- 3), DOI: V10.1080/09500690500336957.

[18] Toulmin, S. E., (2013). The uses of argument (3rd ed.). New York, NY: Cambridge University Press.

[19] Venville, G. J., and Dawson, V. M., (2010). The impact of a classroom intervention on grade 10 students' argumentation skills, informal reasoning, and conceptual understanding of science. Journal of Research in Science Teaching, 47(8), DOI:V10.1 002/tea.20358.

[20] Zohar, A., and Nemet, F., (2001). Fostering students' knowledge and argumentation skills through dilemmas in human genetics. Journal of Research in Science Teaching, 39(1), DOI:V10.100 2/tea. 1000. 